\title{
Effect of Physical and Chemical Mutagenesis in Sunflower [Helianthus Annus L.] on Seed Germination through Induced Mutation
}

\author{
Vijayata P. Jamdhade, Navnath G. Kashid \\ Department of Botany, Vasant Mahavidyalaya Kaij, Dist: Beed.Maharastra, 431123, India
}

\begin{abstract}
Sunflower [Helianthus annus L.] is an annual plant belongs to the compositae (Asteraceae) family. During present studies, the seed of sunflower varieties "Bhanu"; and "SS-56" were treated with different concentrations of chemical mutagens $(0.05 \%, 0.10 \%$ \& $0.15 \%$ for EMS and $0.01 \%, 0.02 \%$ \& $0.03 \%$ for SA). The physical Mutagens like Gamma rays were used @ 10KR, 20R \& 30 KR. After sowing in Petridis it was found that both varieties of sunflower responded differentially to EMS and Gamma rays treatments in respect of seed germination.
\end{abstract}

Keywords: Sunflower, Induced mutation, Seed germination

\section{Introduction}

Sunflower [Helianthus annus L.] is one of the most important oil crops \& is cultivated at 23 million hectare (faostat.fao.org.2009) in more than 70 countries all over the world (de Rodriguez et al., 2002; Simic et al., 2008). Sunflower is an annual herbaceous crop that is propagated by seed only (KPI Inoka \& Nilanthi Dahanayake). Investigation of Seed germination is performed in optimal and control laboratory conditions. The main aim of these investigations was to calculate percentage of seed germination through induced mutation [Jelena S. et al.]Seed germination is a mechanism in which morphological \& physiological alternations result in activation of the embryo. Before germination seed absorbs water, resulting in the expansion and elongation of seed embryo (Mohammad Miransaris, D.L.Smith)

\section{Materials and Methods}

The physical mutagen (gamma rays) and chemical mutagen [EMS-Ethyl Methanesulphonate \& SA (Sodium Azide) were employed as mutagens during present studies. Seeds were irradiated with Gamma rays from Govt. Institute of Science, Caves road, Aurangabad (MS), India.

The seed of sunflower Bhanu and SS-56 cultivars were collected from dry farming research station, Solapur 413002(MS) India. The seeds treated with different doses of gamma rays viz. $10,20,30 \mathrm{kR}$, and EMS viz $0.05 \%, 0.20 \%, 0.15 \% \quad \& \quad \mathrm{SA}$ (Sodium Azide) viz. $0.01,0.02,0.03 \%$ along a control.

The treated seeds were presoaked in distilled water for $6 \mathrm{hrs}$. at room temperature followed by six hour immersed in mutagenic solutions. These seeds were thoroughly washed under running water for $4 \mathrm{hrs}$. A set of 300 seeds from each treatment were sown in randomized blocked design [RBD] with three replications along with control for rising M1 generations during Rabi 2016. The seeds were sown at the distance of $15 \mathrm{~cm}$ in line and $30 \mathrm{~cm}$ between the rows. The experiments were conducted in botanical Garden at Dr.
Babasaheb Ambedkar Marathwada University Aurangabad (MS) India. Recommended Agronomic practices were employed for preparation of field sowing and subsequent management of other population.

Seed germination $\%$

Seed germination $\%$ was recorded at $10^{\text {th }}$ day after sowing in Petri dishes for pilot experiment.

\section{Seed germination $\%=\frac{\text { No. of Seed Germination }}{\text { No. of seeds sown }} \times 100$}

Statistical data were calculated using the following formulae:

Mean $=\frac{\sum X}{n}$

Variance $=\left(\sum X^{2} / n\right)-X^{2}$

Std. Deviation $(\mathrm{SD})=\sqrt{\text { Variance }}$

Standard Error $(\mathrm{SE})=\frac{S D}{\sqrt{N}}$

\section{Results and Discussion}

During present studies effect of the different doses or concentrations of gamma rays, sodium azide and EMS treatment on percentage of germination of BHANU \& SS-56 varieties of sunflower was calculated. The percentage of seed germination in the control as well as in the treated plants of sunflower. They analysis of variance revealed significant differences among treatment intensities on germination. In sunflower seed the maximum number of seed germination as noticed on $10^{\text {th }}$ day after sowing in both varieties, namely Bhanu and SS-56. In control the germination percentage calculated was $90 \%$ in Bhanu and 98\% in SS-56 respectively. The findings of the inhibitory of chemical mutagens in the present study on reduction in seed germination were notified for further studies. The seed germination could be distinctly seen in variety Bhanu in

\section{Volume 5 Issue 6, June 2016}




\section{International Journal of Science and Research (IJSR) \\ ISSN (Online): 2319-7064}

Index Copernicus Value (2013): 6.14 | Impact Factor (2015): 6.391

variety in SS-56 on the other hand a mixed pattern of simulation/inhabitation could be noticed in the gamma rays, EMS \& SA treatment. (Ganesh B.et.al)

EMS treatment revealed a gradual increasing trend in germination from higher to lower doses in SS-56 varieties. The germination ranged from 90 to $94 \%$ in SS-56 varieties. On the other hand decreasing trend in germination from lower to higher doses in Bhanu varieties was noticed. The percentage of germination was in range within 96 to $90 \%$ in Bhanu variety of sunflower.

The SA treatment resulted in reducing seed germination percentage at all its concentration in variety of SS-56. At $(0.03 \%)$ concentration, seed germination percentage noticed was $68 \%$ but decreasing trend in germination from lower to higher doses in SS-56 variety. The germination percentage ranged from 68 to $72 \%$. On the other hand, in the variety Bhanu with $(0.02 \%)$ concentration very low seed germination percentage $(66 \%)$ was recorded. Doses such as $(0.01 \% \& 0.03 \%)$ are higher than $(0.02 \%)$ and percentage of germination was $68 \%$ \& $70 \%$ respectively.

In present studies reduction or stimulation in seed germination might be due to the effect of mutagens on the meristematic tissues of the seed (L.K.Sharma et. al.). The decrease in the seed germination at the higher doses/concentration of the mutagens may be attributed to disturbances at cellular level (caused either at physiological level or physical esculentus) germination percentage generally decreased with increasing doses/concentrations of gamma rays and ems reduced germination percentage with increasing doses of gamma radiations has also been reported in Pinus (Thapa 2004), Rye (Akgun \& Tosum, 2004) \& chickpea (khan et al., 2005 \& Toker et al., 2005).

Germination indicated as an inhibitory feature at all the three concentrations of mutagen treatment of Gamma ray to the variety SS-56. In variety Bhanu except middle concentration $(20 \mathrm{KR})$ at the remaining two concentrations (10KR \&30KR) the germination percentage showed inhibitory effect and which was ranged from $90 \%$ to $98 \%$ in SS-56 \& $92 \%$ to 94\% in Bhanu varieties.

In the present investigation it was found that the two varieties of the sunflower responded differentially to EMS and Gamma rays treatments in respect of seed germination. In the present investigation $(0.05 \%)$ EMS, (10KR) Gamma ray is same germination percentage (96\%) and (20KR) Gamma ray in variety of Bhanu could be due to less damage of all cell material and the resultant differential chemo sensitivity feature. On the other hand SS-56 variety of sunflower the gamma ray $(10 \mathrm{KR})$ and $(20 \mathrm{KR})$ is the damages less to cell material (Navnath G. Kashid and Mukund P. Kulthe).

The mutagenic treatment of gamma ray caused considerable reduction in seed germination. Observations were recorded by Badere R.S. and Choudhary (2007) in Lentil, Biradar (2004), Shinde (2007) in pigenopea.

\section{Conclusion}

Morphological and physiological alternations result in activation of the embryo and germination of seed takes place. Productivity of crop plant is based on health of seeds. Mutation helps alteration of genome and results in mutated strains which may superior than their stock. To check possibility of alteration present piece of work will be helpful in future.

\section{Acknowledgement}

Authors are thankful to Professor and Head, Department of Botany, Dr. Babasaheb Ambedkar Marathwada University, Aurangabad and Principal, Vasant Mahavidyalaya, Kaij for their help and encouragement during this endeavor.

Table 1: The effect of mutagens on seed germination in sunflower [Helianthus annus L.]

\begin{tabular}{|c|c|c|}
\hline \multicolumn{3}{|c|}{ VARIETY SS-56 } \\
\hline Mutagen & Dose/ Concentration & Germination (\%) \\
\hline CONTROL & - & 98.00 \\
\hline \multirow{3}{*}{ EMS (\%) } & 0.05 & 90.00 \\
\cline { 2 - 3 } & 0.10 & 92.00 \\
\cline { 2 - 3 } & 0.15 & 94.00 \\
\hline \multirow{3}{*}{ SA (\%) } & 0.01 & 72.00 \\
\cline { 2 - 3 } & 0.02 & 70.00 \\
\cline { 2 - 3 } & 0.03 & 68.00 \\
\hline \multirow{3}{*}{ GAMMA RAYS } & $10 \mathrm{KR}$ & 98.00 \\
\cline { 2 - 3 } & $20 \mathrm{KR}$ & 95.00 \\
\cline { 2 - 3 } & $30 \mathrm{KR}$ & 90.00 \\
\hline
\end{tabular}

$$
+/-\mathrm{SE}=2.09
$$

Table 2: The effect of mutagens on seed germination in sunflower [Helianthus annus L.]

\begin{tabular}{|c|c|c|}
\hline \multicolumn{3}{|c|}{ VARIETY BHANU } \\
\hline Mutagen & Dose/ Concentration & Germination (\%) \\
\hline CONTROL & - & 90.00 \\
\hline \multirow{3}{*}{ EMS (\%) } & 0.05 & 96.00 \\
\cline { 2 - 3 } & 0.10 & 92.00 \\
\cline { 2 - 3 } & 0.15 & 90.00 \\
\hline \multirow{3}{*}{ SA (\%) } & 0.02 & 70.00 \\
\cline { 2 - 3 } & 0.02 & 66.00 \\
\cline { 2 - 3 } & 0.03 & 68.00 \\
\hline GAMMA RAYS & $10 \mathrm{KR}$ & 96.00 \\
\cline { 2 - 3 } & $20 \mathrm{KR}$ & 94.00 \\
\cline { 2 - 3 } & $30 \mathrm{KR}$ & 92.00 \\
\hline
\end{tabular}

\section{References}

[1] Akgun I., Tosum M. (2004): Agricultural \& Cytological Characteristics of M1pernnial Rye (Secalemontanum Guss.) As Effected By The Application Of Different Doses Of Gamma Rays, Pakistan Journal Of Biological Science,7(5);827-833

[2] Badare R.S. And Choudhry A.D. (2007): Effectively And Efficiency Of Gamma Rays, Sodium Azide And Ethy Methane sulphonatein,Linseed.Bionfolet.4(3):181187

[3] Biradar A.B. (2004): Gamma Rays and Ethyl Methane Sulphonate (Ems) Induces Mutation Studies In 


\section{International Journal of Science and Research (IJSR)}

ISSN (Online): 2319-7064

Index Copernicus Value (2013): 6.14 | Impact Factor (2015): 6.391

Pegionpea (CajanusCajan L.)Millsp.1 Ph.D-Thesis. MpkvRahuri.

[4] Shinde M.D (2007): Assessment Of Variability In M, Lines Of Pigeonpea (CajanusCajan L.) (Millsp.1 Ph.DThesis, Mpkv,Rahuri.)

[5] D. Dhakshanamworthy, R. Sevaraj $^{1}$, A Chidambaram Physical And Chemcial Mutagenesis In SatrophaCurcasl To Induce Variability In Seed Germination, Growth\& Yield Traits.

[6] De Rodriguez, Dj- Romero-Grazia.J, RodriguzGarcia. R, Angulo-Sanchez.J.L(2002): Characterization Of Protein From Sunflower Leaves And Seeds; Relationship Of Biomass And Seed Yield. In Janick, J. Whipkey, A.[Eds.], Trends In New Crop And New Uses Proc. Of The Aaic Fifth National Symposium, Perdue University, Usa, P.P.143-149

[7] Fostat, Production, Prodstat, Crops (Online) Accessibility OnHttp://Faostat.Fao.Org(2009) ; Food \&Agriculture Organization Of The United Nations.

[8] G. S. Dhulgande, D. S. Ghogare\& D.Dhale (2015): Mutagenic Effect On The Seed Germination , Seeding Growth And Seeding Survival Of Ped (PisumSatium L.)International Journal Of Current Research In Bioscience And Plant Biology. ISSN-2349-8080 $\begin{array}{llll}\text { Volume } 2 & \text { Number } & \text { 4(April-2015) Pp.59-64 }\end{array}$ Www.Ijerbp.Com

[9] Ganesh B.Kukarni\&Umesh P. Mogle (2013):Effects of Mutagen on Chlorophyll Mutation In Horse Gram (Macrotylomaunifloum (Lam) Verdcourt). Botany Department, R.G. Bagdia Arts, S.B. LakhotiaCommAnd R. Enzonji Sci. College, Jalna(M.S.) India 431203. ISSN:2229-2469(Print), Bioscience Discovery,4(2):214-219,July 2013.

[10] Jelena S. Mrda, Nenad Z. Dusanic, Velimir B. Radic\& Vladimir J. Milkic(2010) :- Effect Of Different Substratum On Treated Sunflower Seed Germination. Institute Of Field \& Vegetable Crops, MaksimaGorkog 30, 21000 Novisad, Serbia Journal Of Agriculture Science Vol.55 No.1, 2010. Page No.1-8

[11] Khan M.R., A.S. Qureshi, A.H. Syeed, M. Ibrahim (2005). Genetic Variability Induced By Gamma Irradiation And Its Modulation With Gibberellic Acid In M2 Geeratio Of Chickpea (Cicerarietium L.). Pakistan Journal Of Botany,37(2),285-292.

[12] KpiInoka\&NilanthiDahabayak : Effect Of Plnat Growth Regulators On Micro-Propagations Of Sunflower [Helianthus Annus L.] Dept. Of Agriculture Biology, Faculty of Agri., University Of Ruhuyna, Mapalana, Kamburupitiya, Srilanka. International Journal

[13] Kumar A,M.N. Mishra(2004). Effect Of GammaRays,Ems And Nmu On Germionation , Seedling,Vigour,Pollen Viability And Plant Survival In M1 \&M2 Generation Of Okra (Abelmoschusesculentus (L.) Moench).Advances In Plant Science, 17(1),295-297.

[14] L.K. Sharma, manishaKaushal, m.I.S. Gill AndS.K.Bali (2013): Germination And Survival Of Citrus Jambhiri Seeds And Epicotyls After Treating With Different Mutagens Under In Vitro Conditions.Middle-East Journal Of Scientific Research. 16(2): 250-255,2013ISSN.19909233.CIDOS

[15] Mohammad Minransari,D.L.Smith.: Plant Hormones And Seed Germination,Environmental \& Experimental
Botany

JournalHomepage:Www.Elsevier.Com/Locate/Envexpb ot

[16] Navnath G. Kashid(2013); Mutagenic Effect Of Ethyl Methane Sulphonate And Sodium Azide On Pos Characters In Chickpea[ CicerarietinumL.]International Journal of Science \& Research (IJSR)ISSN(ONLINE) : 2319-7064(2014):5.611

[17] P. Raja Ramesh Kumar \& S. VenkatRatnam(2010): Mutagenic Effectiveness And Efficiciency In Variety Of Sunflower [Helianthus annus L.]By Separate \&Combined Treatment With Gamma Ray And Sodium Azide.African Journal Of Biotechnology Vol. 09(39),PP. 6517-6521,27 September,2010.

[18] Http://Www.Academicjournals.Org/Ajb

[19] Rogelio Marchetti (Dec.2012) :Evaluation Of Four Treatments To Break Seed Dormancy Of Sunflower Seeds Hybrids. A Research Study For The Master Of Science In Agriculture And Natural Resources Degree University Of Tennessee.

[20] Shinde M. D.: Assessment of variability in M, Line of pigeonpea (Cajonuscajan) ISSN 1684-5315@2010 Academic Journals.

[21]L.Millisp.1. M.Sc.Thesis M.P.K.V. Rahuri.

[22] Thapa C.B(2004). Effect Of Acute Expose Of Gamma Rays On Seed Germination And Seedig Growth Of PinusKesiyaGord And P. Wallichiana A.B. Jacksour Nature, 2,13-17

[23] ThitipornMachikowa, ThanawitKulrattanarak, And SodcholWonprasaid (2013):Effects Of Ultrasonic Treatment On Germination Of The Synthetic Sunflower Seeds,

[24] World Academy Of Science, Engineering And Technology International Journal Of Biological, Biomolecular , Agricultural , Food And Biotechnological Engineering Vol:7,No:1,2013. 